\title{
「場」の機能に配慮した国内大都市のバス停周辺環境のあり方に関する研究
}

\section{A STUDY ON ‘PLACE’ FUNCTION OF THE BUILT ENVIRONMENT SURROUNDING BUS STOPS IN JAPANESE LARGE CITIES}

\author{
三浦詩乃*1, 吉田宗人*2, 田中伸治*3, 有吉 亮*4 \\ Shino MIURA, Munehito YOSHIDA, Shinji TANAKA \\ and Ryo ARIYOSHI
}

\begin{abstract}
The research aims to clarify the spatial elements and their appropriate layout of the environment surrounding bus stops co-existing with the function of "Place" for street users. The main target is Japanese representative transit environment planning in Edogawa ward. The paper concluded the target scheme hasn't shaped attachment to the environment by bus users and neighbors although it has achieved most of the place function performance index. It also indicated the frontage land use and location of the seating might influence users' stational activities, and the recognition as a local open space would enhance users' attachment to a bus stop.
\end{abstract}

Keywords : Public transportation, Transit stop, Pedestrian activity, Geometry of streets, Placemaking 公共交通, 交通結節点, 歩行者活動, 街路構造, プレイスメイキング

\section{1.はじめに}

\section{1 背景}

バスや路面電車等の路上公共交通の利用者にとって、結節点空間 は各サービスへのゲートにあたる。しかし、用地確保、それに伴う 沿道地権者との合意形成や占用手続き等において、サービス供給側 が制約や負担をかかえており 1)、アクセス性や滞在快適性の向上、 複数交通手段間の連携等、利用者主眼の環境づくりの観点から多く の課題が残る。地域拠点性を持たせる開発や周辺市街地の都市活動 との連携に配慮した駅前広場の再整備注 1)が進む鉄道駅とは対照的 である。

こうした状況は、路上公共交通結節点空間が最低限の交通処理機 能保持にとどまれば良い、またはとどまるしかないという認識で、 供給側と地域との間で運用協力体制が築けていないことが一因とみ られる。今後、「モビリティ・アズ・ア・サービス $(\mathrm{MaaS}) 」 の$ 普及な どに伴い、路上公共交通結節点空間には多機能化や利用者にとって のレジビリティ(機能のわかりやすさ)がますます求められていくと みられ、現況の課題解決が急務である。

そこで本研究では、地理学や社会学分野を中心に提示されてきた 概念で、利用者や地域住民・就業者にとって、居場所かつ活動の場 となる潜在力のある空間を指す 2)「Place(場)」という概念に着目す る。地域内移動を支える基幹公共交通であるバスの結節点である、
バス停は本来、交通処理機能だけではなく「場」の機能も持つとみ られる。しかし、国内においてバス停の「場」の機能について体系 的に論じ、空間デザインと運用へ知見の応用を試みた研究は少ない。

\section{2 既往研究と本研究の位置づけ}

(1)既往研究

日本国内におけるバス停の実態研究としては、まず、バス停の空 間整備状況を明らかにした研究が挙げられ、水田3)や平原4) が、空間 類型と不十分な整備実態について指摘している。維持管理について は、竹本5) は、現場の状況に応じた弾力的な運用と関係ステークホル ダーの役割分担、上屋設置後の安全性の確保、官民協働による維持 管理、前面建物スペースの活用、バスロケーションシステムの導入 の必要性を挙げている。

特に、バス停利用者の挙動に着目したものには、平野ら 6)がバス 利用者の待ち行動の具体的内容や個人属性とバス待ち抵抗との関係 について、アクティビティ調查、アンケート調查を行っている。そ の結果、コンビニ利用、ベンチへの着座ができる、または小公園的 に整備されたバス停では、バス利用者の待ち抵抗を緩和させること を明らかにした。また、バス停利用者とその他歩行者の行動特性に 関する研究として、細川 7)は類型に応じた待ち行動と通過行動の関 係を示した。近年は、鈴木ら 8)のようにバス停を構成する照明等ツ ールの改善実験も実施されている。

$* 1$ 東京大学大学院新領域創成科学研究科 特任助教 - 博士 (環境学)

Project Assist. Prof., Graduate School of Frontier Sciences, The Univ. of Tokyo, Dr.Env.

$* 2$ 倉敷市役所建築指導課 技師 · 博士 (環境学)

*3 横浜国立大学大学院都市イノベーション研究院 准教授・博士 (工学)

*4 横浜国立大学大学院都市イノベーション研究院 特任准教授・博士 (工学)

Engineer, Building Guidance Division of Kurashiki City Government, DrEnv. Assoc. Prof., Graduate School of Urban Innovation, Yokohama National Univ. Dr.Eng.

Project Assoc. Prof., Graduate School of Urban Innovation, Yokohama National Univ., Dr.Eng. 
Table 1 Expected effects for public transportation users/non-users by placemaking of transit stops

\begin{tabular}{|l|l|l|}
\hline Target & Steps & Expected effects \\
\hline \multirow{4}{*}{$\begin{array}{l}\text { Transit } \\
\text { stops }\end{array}$} & $\begin{array}{l}\text { Placemaking } \\
\text { : Attractive Quality } \\
\text { as Local Public Space }\end{array}$ & $\begin{array}{l}\text { Reducing Barrier to Service } \\
\text { Dereate opportunities for } \\
\text { Access by Local Non-Users } \\
\text { Daise Users' Satisfaction on } \\
\text { Access \& Waiting Environment }\end{array}$ \\
\cline { 2 - 3 } & $\begin{array}{l}\text { Functional Update of Space } \\
\text { Better Access to Service } \\
\text { Physically and Informatically }\end{array}$ & $\begin{array}{l}\text { Fundamental Improvement } \\
\text { of Transportation Service } \\
\text { PModal Change of Non-Users }\end{array}$ \\
\hline $\begin{array}{l}\text { Roadbed } \\
\text { (Lanes) }\end{array}$ & $\begin{array}{l}\text { Operational and Hardware } \\
\text { Improvement of Service }\end{array}$ & $\begin{array}{l}\text { Daise Users' Satisfaction on } \\
\text { Each Trip }\end{array}$ \\
\hline
\end{tabular}

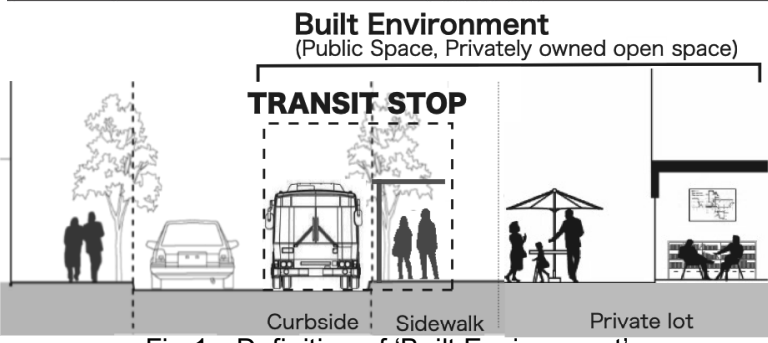

Fig.1 Definition of 'Built Environment'

\section{(2)本研究の位置づけ}

以上の既往研究から、国内のバス停ではバス利用者と歩行者双方 に配慮した包括的な空間づくり、そのために公共空間と民地の一体 的な活用が必要であることが明らかにされてきた。つまり、1)バス 停および路上単体でなく、周辺含む官民空間を面的に再デザイン対 象と寸るように交通施設整備に都市デザイン的手法を取り入れるこ と、そのために 2)公共交通利用者、および前面地権者を含むバス停 周辺環境を日常的に用い得る地元主体双方の参加を促寸事業スキー ムのあり方が求められている。

本研究で着目する「場」の機能の観点では、通行以外の利用者の 挙動を街路空間の占用として一意にみなさず、付随活動の多様性が 尊重される。バス利用者にとっては待ち環境の充実、バス非利用者 にとっては移動以外の活動目的での空間利用価値発掘につながる。 交通処理機能の向上のみを考慮する場合よりも、デザインや運用の 議論に、バス停利用者や地元が参加する契機となることが期待され、 上記 2)にまで踏み込むことができるとみられる(Table 1)。バス停の 「場」の機能を評価し、その機能を高める方策を示寸本研究は、既 往研究では未だ明らかにされていない地域参加型の事業スキームを 提示し、持続的な結節点運用に資するものである。

なお、「場」の機能を高める手法、いわゆる「プレイスメイキング」 の知見を交通利便施設、交通安全施設に活か寸研究は未だ少ない。 国際的には BRT の停留所に対する ITDP9)、バス停と歩行者の共存 の観点から Transport for London ${ }^{10)}$ な゙、、自治体レベルで歩道上の 多機能化を推奨するガイドラインが提示されているが、いずれも幅 員が十分に大きく、路上のみで用地を確保できる想定で、官民空間 を一体的に用いた結節点デザイン手法を提示していない。

\section{3 目的と方法}

本研究は、国内大都市における「場」の機能に配慮したバス結節 点周辺環境の空間要素とその配置のあり方、およびその実現に求め られる、結節点の空間デザインから維持管理に至る事業スキームの あり方を提示することを目的とする。本研究における結節点周辺環 境とは、路上結節点に隣接した屋内外の建造空間(Fig 1)を指寸。

まず、「場」の機能の観点から公共交通結節点やトランジットモー
Table 2 Genealogy of Placemaking for transit stops in U.S.

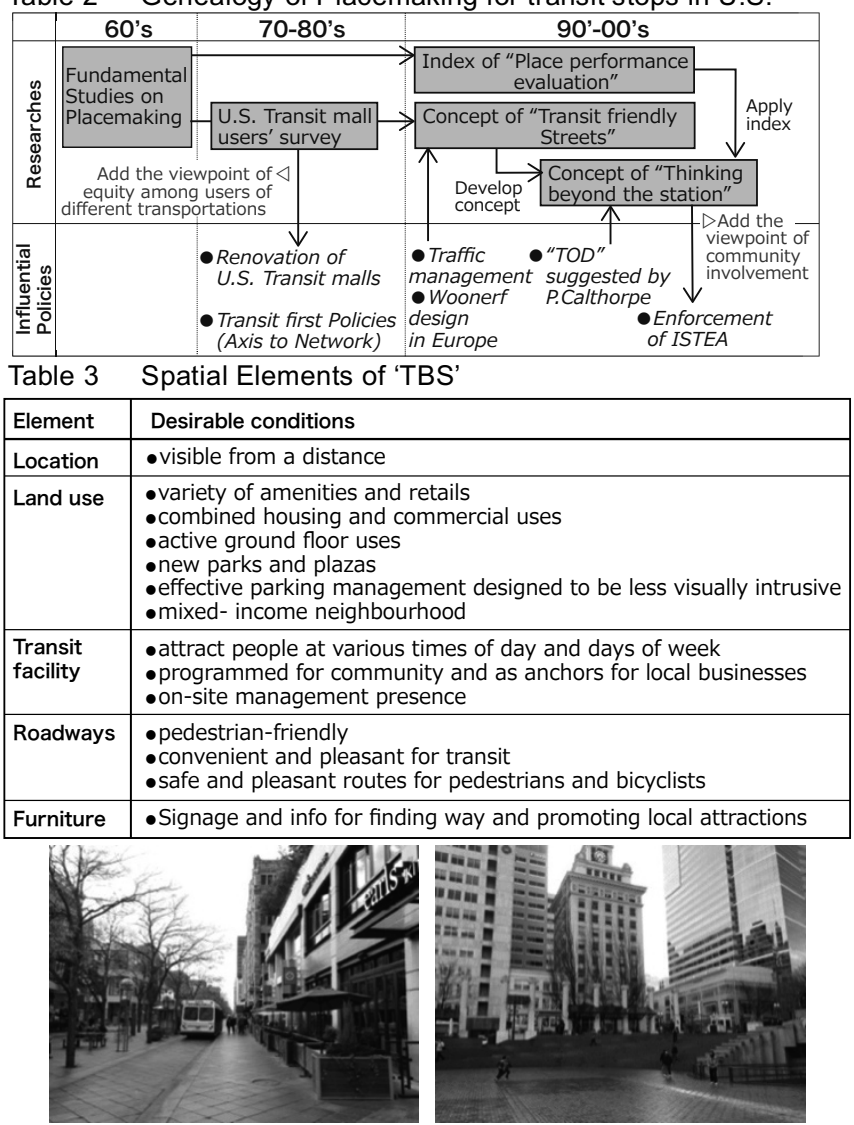

Photo 1 Examples of TBS design

Table 4 Suggested tools for community

For Assesment of current condition and preliminary oppotunities

-Mapping(400m radius):

population, land use, route to transit,facilities, retails, open spaces, destinations

-Photo documentation $\bullet$ Questionnaire $\bullet$ Pedestian counts $\bullet$ Walk audit - Stakeholder meeting for 10 ideas (entitled as 'Power of $10^{\prime}$ )

For Community Involvement to create future vision

-Walking Focus Survey by viewpoints of 'place' performance

$\bullet$ Workshop •Site modelling •Inspiration game •Group presentation

ルの再デザイン実績のある米国のプレイスメイキング手法に着目し、 文献調査により、手法プロセスと評価指標を整理した上で、国内の 基準における「場」の機能への対応状況を明らかにする(第2章)。次 に、国内の代表的な路上結節点高質化事例を対象に、事業スキーム の実態(第3章)を明らかにする。また、第 2 章における評価指標をふ まえながらバス停利用者アンケート調查、観察調査を行い、同事例 の「場」としての性能(第4章)、「場」としての利用をもたらす空間要 素(第 5 章)を示す。総括として、国内事例の事業スキームの成果と、 「場」の機能に配慮した路上公共交通結節点の空間要素とその配置、 その実現に求められる事業スキームのあり方を示す。前述のとおり、 バス停利用者と地元の参加に焦点をあて、参加の必要性とその契機 を検証し、事業スキームのあり方提案に反映する(第6章)。本研究で 「参加」とは、整備や管理に係るコストや用地、マンパワーの提供 を指すとともに、その合意形成プロセスへの参画を含むものとする。

上記方法は、4 章(アンケート、観察調查)により地元内外のバス停 利用者、3 章(長年管理に携わる行政へのヒアリング)によりその他 地元住民(バス停周辺環境利用者および前面地権者) という、参加の 対象となり得る住民の実態に関するデータを収集しており、検証に 
十分と判断した。

\section{2. 公共交通結節点のプレイスメイキング手法と国内での対応 2. 1 公共交通結節点のプレイスメイキング手法}

(1)手法構築に至るまでの系譜

米国では、滞在性、社会交流や地域文化を育む活動の活性化によ る公共空間の価值の底上げを動機とし、都市デザイン政策提言団体 Project for Public Spaces を中心に 60 年代以降、プレイスメイキン グのノウハウを蓄積してきた。プレイスメイキングでは、公共交通 結節点を地域活性化に資する空間として位置づけ ${ }^{11)} 、 70$ 年代から デンバー市、ミネアポリス市、ポートランド市、ニューヨーク市等 の先進自治体で整備されていたトランジットモールの再評価を実施 してきた ${ }^{11), 12)}$ （前頁 Table 2)

(2)「Thinking beyond the Station」の提唱

同団体を中心に、トランジットモールの再評価を経て得た知見と 公共交通指向型の開発方針を組み合わせて「Thinking Beyond the Station(以下 TBS)」13) という概念を提唱した(前頁 Table 3)。広場や 周辺の公共空間と一体的に形成された結節点では、本来の交通処理 機能に加え、コミュニティ交流等の多様な活動を醸成し得るという ものだ。TBS は、結節点の立地、周辺土地・建物利用、結節点の設 備、路上空間の運用、ファニチャーデザインに焦点を当てて、望ま しい条件に再デザインまたは運用するものである(前頁 Table 3)。こ うした TBS の概念に基づいたデザイン事例として、民間オープン カフェの滞在設備、中央帯への可動式座り場増設といった滞在空間 の多様性、気軽に乗れる結節点間隔を備えたデンバー市 16 番街モ ール(前頁 Photo1 左)や、広場と一体的なポートランド市のパイオニ ア・コートハウス・スクエアの結節点など(Photo1 右)が挙げられて いる ${ }^{14)}$ 。実現に向けては、立地の決定から地元意見を吸い上げると もに、論拠となるデータも協働して取るツールキットを作成してい
る(前頁 Table 4)。さらに、街路や他の公共空間に対して実用してき た「場」の性能評価指標 ${ }^{13)}$, 15) を公共交通結節点の診断に応用してお り、地元ステークホルダーが主体的に優先したい指標と適用範囲を 決定する。指標は 1)利用と活動状況、2)アクセスとつながり、3)快 適性とイメージ、4)利用者およびコミュニティの交流・絆(社会性)と いう、4つの観点から成る(Table 5)。公共交通利用者および地元主 体を主眼とした TBS 概念の下、「場」の性能向上を目的とした実用 実績がある本指標を、以降の国内結節点空間の分析の切り口とする。

\section{2 日本国内基準下での「場」の性能への対応状況}

(1)道路占用許可基準における規定

日本の路上結節点施設は各自治体が定める道路占用許可基準に従 う必要があり、同基準は道路法のもと、設備が通行の阻害にならな いこと、安全管理のしや寸さに重点が置かれる。より具体的傾向を みるために、インターネット上で基準の公開がみられる政令指定都 市と第 3 章で主対象とする東京都江戸川区の 12 都市(2019 年時点) を対象に、前述 TBS の調查結果(Table3)を参照し、バス停および周 辺環境利用者の活動に影響する設備「ベンチ」「上屋」「バス停総合 案内板」(バス利用者及び付近歩行者の利便性、快適性)、「バス停上 屋上広告板」(視認性)、「案内標識/公共表示板/掲示板」(地域の情報 提供)の計 5 項目について掲載の有無及び関連条文を整理した (Table 6：ベンチ・上屋寸法は一般歩道への設置時の值を掲載)。

ベンチの占用者 (9 件)や材質・構造(10 件)に関しては、2013 年の 国土交通省道路局長による通達「ベンチ及び上屋の道路占用の取扱 いについて」注2)に従った共通点がみられた。占用者は「地方公共団 体、商店街振興組合、町内会、公共交通およびタクシー事業者団体、 その他これらに準ずる的確な管理能力を有すると認められる団体や それに準ずる者」を認め、材質・構造は路面固定を定める点である。 他方、大きさと占用場所については、自治体間で詳細規定の有無が 二分される。大きさは「長さ $3 \mathrm{~m}$ 以下、幅 0.5 (または 0.7$) \mathrm{m}$ 以下」

Table 5 Summary of Place performance evaluation index proposed by Project for Public Spaces

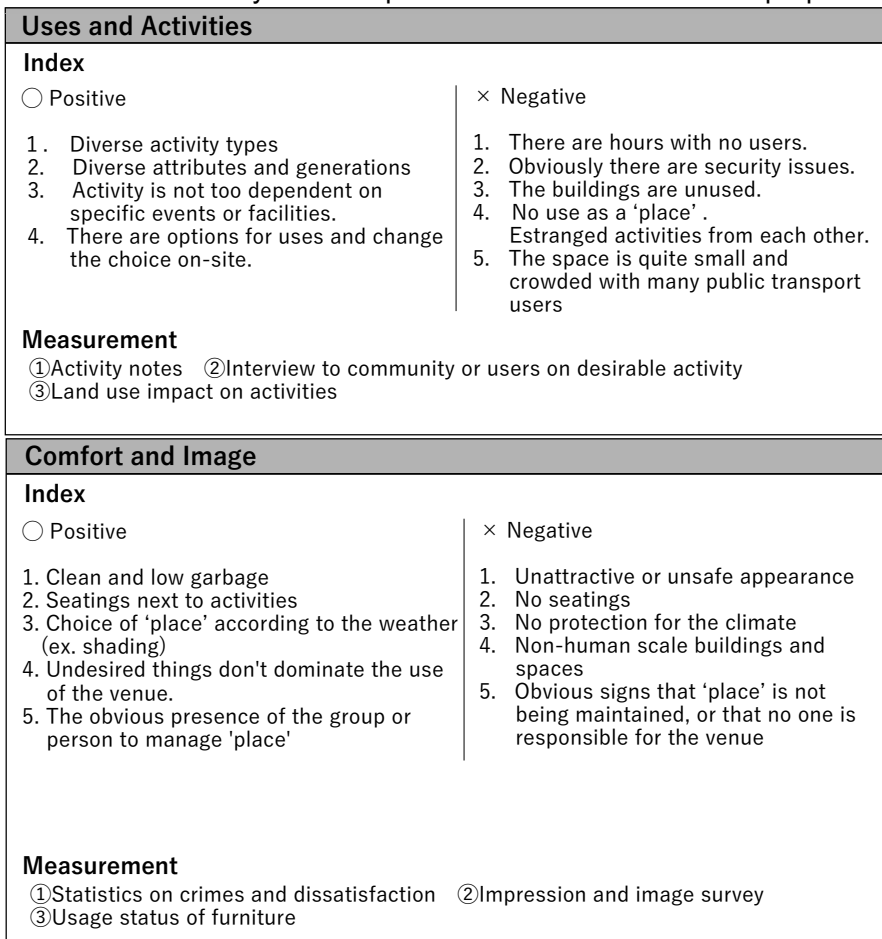

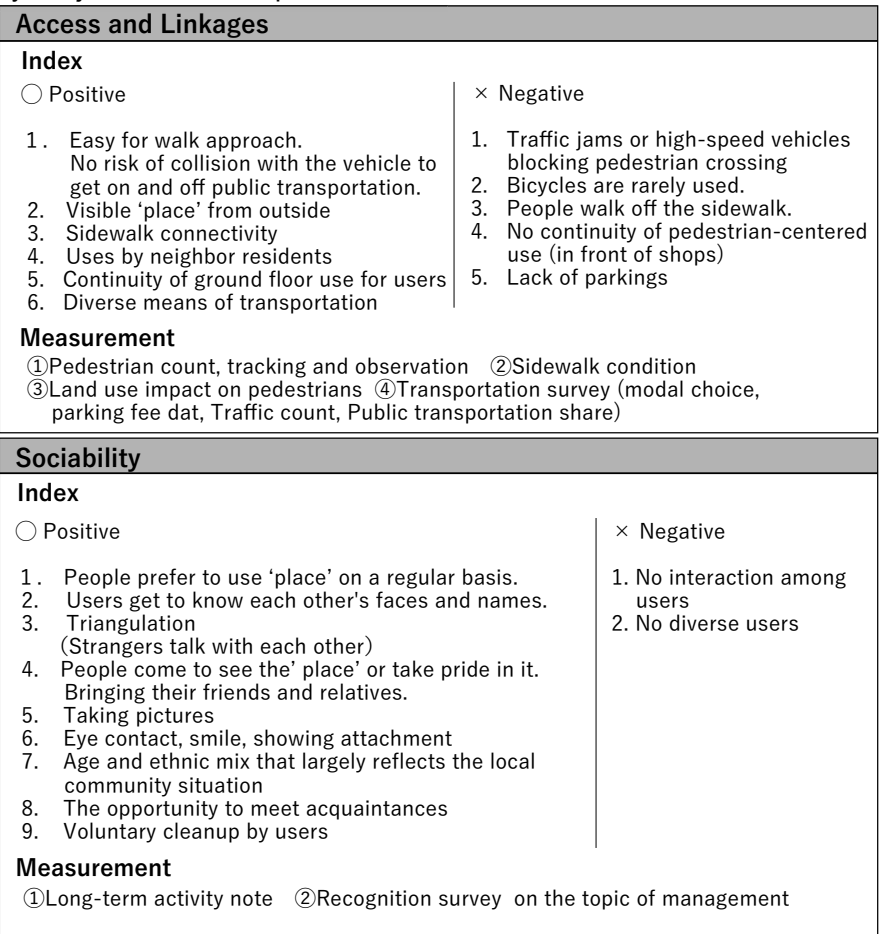


Table 6 Road occupancy permission standards of 12 cities

\begin{tabular}{|c|c|c|c|c|c|c|c|c|c|c|c|c|c|}
\hline \multirow[b]{2}{*}{ City } & \multicolumn{5}{|c|}{ Bench } & \multicolumn{5}{|c|}{ Bus shed } & \multirow{2}{*}{\begin{tabular}{|c|} 
Bus \\
info \\
board \\
\end{tabular}} & \multicolumn{2}{|c|}{ Bulletin board,Wayfinding } \\
\hline & $\begin{array}{l}\text { Authorized } \\
\text { occupants }\end{array}$ & Size & Layout & Location & Facility & $\begin{array}{l}\text { Authorized } \\
\text { occupants }\end{array}$ & Size & Layout & Location & Advertisement & & $\begin{array}{c}\text { Authorized } \\
\text { occupants/Objective }\end{array}$ & Size \\
\hline 1.Nagoya & $\begin{array}{l}\text { Municipality, } \\
\text { Merchant assoc., } \\
\text { Bus Operator }\end{array}$ & $\begin{array}{l}L \leqq 3 m, \\
W \leqq 0.5 m\end{array}$ & Sidewalk & & $\begin{array}{l}\text { Fixed, } \\
\text { Durable }\end{array}$ & Bus Operator & $\begin{array}{l}L \leqq 12 m \\
W \leqq 2 m\end{array}$ & On Sidewalk & & & & $\begin{array}{l}\text { Govt., Municipality, } \\
\text { Merchant assoc. }\end{array}$ & $L \leqq 1.5 \mathrm{~m}$ \\
\hline 2.Kyoto & $\begin{array}{l}\text { Municipality, } \\
\text { Merchant/Neighbor } \\
\text {-hood assoc., } \\
\text { Bus/Taxi Operator }\end{array}$ & $\begin{array}{l}L \leqq 3 \mathrm{~m}, \\
W \leqq 0.5 \mathrm{~m}\end{array}$ & $\begin{array}{l}\text { Sidewalk, } \\
\text { Near curb }\end{array}$ & & Fixed & $\begin{array}{l}\text { Bus/Taxi } \\
\text { Operator }\end{array}$ & $\begin{array}{l}L \leq 12 m, \\
W \leqq 2 m\end{array}$ & $\begin{array}{l}\text { On Sidewalk } \geqq \\
2.5 \mathrm{~m}, \mathrm{EW} \geqq 3.5 \mathrm{~m}\end{array}$ & & \begin{tabular}{|l} 
For Bus users' \\
convenience, \\
Local public \\
activities \& \\
Admin. Property \\
\end{tabular} & & $\begin{array}{l}\text { Govt., Municipality, } \\
\text { Merchant/Neighbor- } \\
\text { hood assoc. }\end{array}$ & $W \leqq 2 m$ \\
\hline 3.Osaka & $\begin{array}{l}\text { Municipality, Bus } \\
\text { Operator }\end{array}$ & $\begin{array}{l}L \leqq 2 \mathrm{~m}, \\
\mathrm{~W} \leqq 0.5 \mathrm{~m}\end{array}$ & $\begin{array}{l}E W \geqq \\
2-3 m, \\
\text { Near curb }\end{array}$ & $\begin{array}{l}\text { At Bus stop only, } \\
\text { Near lighting }\end{array}$ & $\begin{array}{l}\text { Fixed, } \\
\text { Durable }\end{array}$ & $\begin{array}{l}\text { Bus/Taxi } \\
\text { Operator }\end{array}$ & $\begin{array}{l}L \leq 12 m, \\
W \leqq 2 m\end{array}$ & $\begin{array}{l}E W \geqq 2 \mathrm{~m} \text {, Distance } \\
\text { from Private lot } \geqq \\
1.5 \mathrm{~m}\end{array}$ & $\begin{array}{l}20 \mathrm{~m} \\
\text { Interval }\end{array}$ & $\begin{array}{l}\text { For Bus users' } \\
\text { convenience }\end{array}$ & & $\begin{array}{l}\text { Govt., Municipality, } \\
\text { Neighborhood } \\
\text { assoc.,School, } \\
\text { Hospital }\end{array}$ & $\begin{array}{c}\text { W } \leqq 2 \mathrm{~m} \\
\text { Wayfinding: } \\
\text { W } \leqq 0.3 \mathrm{~m}\end{array}$ \\
\hline 4.Kobe & $\begin{array}{l}\text { Municipality, } \\
\text { Merchant/Neighbor } \\
\text {-hood assoc., } \\
\text { Bus/Taxi Operator }\end{array}$ & $\begin{array}{l}\text { Negotiatio } \\
n \text { with } \\
\text { Road } \\
\text { manager }\end{array}$ & $\begin{array}{l}E W \geqq 1- \\
3.5 \mathrm{~m}\end{array}$ & $\begin{array}{l}\text { Negotiation with } \\
\text { Road manager }\end{array}$ & $\begin{array}{l}\text { Fixed, } \\
\text { Durable }\end{array}$ & Bus Operator & $W \leqq 2 m$ & $\begin{array}{l}E W \geqq \\
2-3.5 \mathrm{~m}, \\
\text { Distance from } \mathrm{DB} \geqq \\
60 \mathrm{~cm}\end{array}$ & $\begin{array}{l}\text { Negotiation } \\
\text { with Road } \\
\text { manager }\end{array}$ & $\begin{array}{l}\text { For Bus shed \& } \\
\text { Location system } \\
\text { maintenance }\end{array}$ & & $\begin{array}{l}\text { Govt., Municipality, } \\
\text { Merchant/Neighbor- } \\
\text { hood assoc. } \\
\text { "Incapablity of other } \\
\text { space use }\end{array}$ & $W \leqq 2 m$ \\
\hline 5.Hiroshima & & & & & & & & & & & & For Public Benefit & \\
\hline 6.Fukuoka & $\begin{array}{l}\text { Bus Operator,Local } \\
\text { group }\end{array}$ & $\begin{array}{l}L \leq 3 \mathrm{~m}, \\
\mathrm{~W} \leq 0.5 \mathrm{~m}\end{array}$ & $\begin{array}{l}\text { Sidewalk, } \\
E W \geqq 2-3 \mathrm{~m} \text {, } \\
\text { Distance } \\
\text { from DB } \geqq \\
60 \mathrm{~cm} \\
\end{array}$ & Not on slope & \begin{tabular}{|l|} 
Durable, \\
Lying use \\
protection, \\
Fixed or \\
Heavy base \\
\end{tabular} & & & & ata : Not acce & essible on website & & & \\
\hline 7.Edogawa & $\begin{array}{l}\text { Municipality, } \\
\text { Merchant/Neighbor } \\
\text {-hood assoc., } \\
\text { Bus/Taxi Operator }\end{array}$ & $\begin{array}{l}L \leq 3 \mathrm{~m}, \\
W \leqq 0.7 \mathrm{~m}\end{array}$ & $E W \geqq 1.5 \mathrm{~m}$ & $\begin{array}{l}\text { Station square, } \\
\text { Community road, } \\
\text { Bus stop with } \\
\text { shed } \\
\text { or at hospital }\end{array}$ & $\begin{array}{l}\text { Anti- } \\
\text { deterioration, } \\
\text { Fixed }\end{array}$ & $\begin{array}{l}\text { Bus/Taxi } \\
\text { Operator, } \\
\text { Merchant/ } \\
\text { Neighbor- } \\
\text { hood assoc. }\end{array}$ & $\begin{array}{l}\mathrm{L} \leqq 12 \mathrm{~m}, \\
\mathrm{~W} \leqq 2 \mathrm{~m} \\
\text { or a Harf } \\
\text { width } \\
\text { (Sidewalk } \\
\geqq 4 \mathrm{~m} \text { ) }\end{array}$ & $\begin{array}{l}\text { Near curb, EW } \geqq \\
3.5 \mathrm{~m}, \text { Sufficient } \\
\text { space for DB } \\
\text { On Sidewalk } \geqq 3 \mathrm{~m} \text {, } \\
\text { "Sidewalk } \geqq 2.5 \mathrm{~m} \\
\text { (EW } \geqq 0.5 \mathrm{~m} \text { at } \\
\text { Hospital/for } \\
\text { Elderly) }\end{array}$ & & $\begin{array}{l}\text { For Bus shed } \\
\text { maintenance }\end{array}$ & 0 & $\begin{array}{l}\text { Govt., Municipality, } \\
\text { Neighborhood } \\
\text { assoc. } \\
\text { "Incapablity of other } \\
\text { space use }\end{array}$ & $L \leqq 1.5 \mathrm{~m}$ \\
\hline 8.Yokohama & $\begin{array}{l}\text { Municipality, } \\
\text { Merchant/Neighbor } \\
\text {-hood assoc., } \\
\text { Bus/Taxi Operator }\end{array}$ & $\begin{array}{l}L \leqq 3 \mathrm{~m}, \\
W \leqq 0.7 \mathrm{~m}\end{array}$ & $E W \geq 2 m$ & & $\begin{array}{l}\text { Fixed, } \\
\text { Durable }\end{array}$ & $\begin{array}{l}\text { Bus/Taxi } \\
\text { Operator, } \\
\text { Municipality } \\
\text { Org. capable } \\
\text { of } \\
\text { maintenance } \\
\end{array}$ & $w \leqq 2 m$ & $\begin{array}{l}E W \geqq 2-3.5 \mathrm{~m} \\
\text { Near curb }\end{array}$ & & & & $\begin{array}{l}\text { Govt., Municipality, } \\
\text { Neighborhood } \\
\text { assoc. } \\
\text { "Incapablity of other } \\
\text { space use }\end{array}$ & $L \leqq 1.5 \mathrm{~m}$ \\
\hline 9.Kawasaki & $\begin{array}{l}\text { Municipality, } \\
\text { Merchant/Neighbor } \\
\text {-hood assoc., Bus } \\
\text { Operator }\end{array}$ & $\begin{array}{l}L \leq 3 \mathrm{~m}, \\
W \leqq 0.7 \mathrm{~m}\end{array}$ & $E W \geqq 2 m$ & $\begin{array}{l}\text { Bus stop, } \\
\text { Car prohibited } \\
\text { area(with } \\
\text { Permission by } \\
\text { mayor) }\end{array}$ & \begin{tabular}{|l|} 
Anti- \\
deterioration, \\
Durable
\end{tabular} & \begin{tabular}{|l} 
Bus/Taxi \\
Operator, \\
Org. for \\
Public \\
Benefit
\end{tabular} & $W \leqq 2 m$ & $\begin{array}{l}E W \geqq 2-3.5 m \\
\text { Distance from DB } \\
\geqq 0.75 \mathrm{~m}\end{array}$ & $\begin{array}{l}\text { Not at } \\
\text { Intersection } \\
\text { ( with wall } \\
\text { structure) }\end{array}$ & & & $\begin{array}{l}\text { Municipality, } \\
\text { Neighborhood } \\
\text { assoc. } \\
\text { Wayfinding: Govt. } \\
\text { Municipality }\end{array}$ & $\begin{array}{c}\mathrm{L} \leqq 2 \mathrm{~m} \\
\text { Wayfinding: } \\
\mathrm{L} \leqq 1 \mathrm{~m}\end{array}$ \\
\hline 10.Chiba & $\begin{array}{l}\text { Municipality, } \\
\text { Merchant/Neighbor } \\
\text {-hood assoc., } \\
\text { Bus/Taxi Operator }\end{array}$ & & $E W \geq 2-3 m$ & $\begin{array}{l}\text { Bus stop,Frequent } \\
\text { used facility by } \\
\text { Elderly, Shopping } \\
\text { mall, Community } \\
\text { road, Promenade } \\
\text { etc. }\end{array}$ & $\begin{array}{l}\text { Fixed, } \\
\text { Durable } \\
\end{array}$ & $\begin{array}{l}\text { Bus/Taxi } \\
\text { Operator }\end{array}$ & $W \leqq 2 m$ & $\begin{array}{l}E W \geqq 2-3.5 m \\
\text { Distance from DB } \\
\geqq 0.3 \mathrm{~m}\end{array}$ & & $\begin{array}{l}\text { For bus shed \& } \\
\text { Location system } \\
\text { maintenance }\end{array}$ & 0 & Govt., Municipality & $L \leqq 1.5 \mathrm{~m}$ \\
\hline 11.Niigata & $\begin{array}{l}\text { Municipality, } \\
\text { Merchant/Neighbor } \\
\text {-hood assoc., } \\
\text { Bus/Taxi Operator }\end{array}$ & & $\begin{array}{l}E W \geqq 2- \\
3.5 \mathrm{~m}\end{array}$ & $\begin{array}{l}\text { Bus stop,Frequent } \\
\text { used facility by } \\
\text { Elderly, Shopping } \\
\text { mall, Community } \\
\text { road, Promenade } \\
\text { etc. }\end{array}$ & \begin{tabular}{|l} 
Fixed, \\
Durable \\
\end{tabular} & $\begin{array}{l}\text { Bus/Taxi } \\
\text { Operator,Mer } \\
\text {-chant/Neigh- } \\
\text { borhood } \\
\text { assoc. }\end{array}$ & $w \leqq 2 m$ & $\begin{array}{l}E W \geqq 2-3.5 \mathrm{~m} \text {, } \\
\text { Sufficient space } \\
\text { for } D B\end{array}$ & $\begin{array}{l}\text { Not at } \\
\text { Intersection } \\
\text { ( with wall } \\
\text { structure) }\end{array}$ & $\begin{array}{l}\text { For Bus shed \& } \\
\text { Location system } \\
\text { maintenance }\end{array}$ & & & \\
\hline $\begin{array}{l}\text { 12. Hama- } \\
\text { matsu }\end{array}$ & $\begin{array}{l}\text { Municipality, } \\
\text { Merchant/Neighbor } \\
\text {-hood assoc., } \\
\text { Bus/Taxi Operator }\end{array}$ & & $E W \geqq 2 m$ & $\begin{array}{l}\text { Bus stop,Frequent } \\
\text { used facility by } \\
\text { Elderly,Shopping } \\
\text { mall, Community } \\
\text { road, Promenade } \\
\text { etc. }\end{array}$ & $\begin{array}{l} \\
\text { Fixed, } \\
\text { Durable } \\
\end{array}$ & $\begin{array}{l}\text { Bus/Taxi } \\
\text { Operator,Mer } \\
\text {-chant/Neigh- } \\
\text { borhood } \\
\text { assoc. }\end{array}$ & $W \leqq 2 m$ & $\begin{array}{l}E W \geqq 2-3.5 \mathrm{~m} \text {, } \\
\text { Sufficient space } \\
\text { for DB }\end{array}$ & $\begin{array}{l}\text { Not at } \\
\text { Intersection } \\
\text { ( with wall } \\
\text { structure) }\end{array}$ & & & \begin{tabular}{|l|} 
Only for Public \\
Benefit or \\
Pedestrians \\
"Incapablity of other \\
space use
\end{tabular} & $\leqq 1.0 \times 1.5$ \\
\hline
\end{tabular}

が 6 件、占用場所は、設置後の歩道の「有効幅員(原則 $2 \mathrm{~m}$ 以上)」 の記載が 7 件で、記載された寸法は先の通達に従う。配置は、車道 寄り (2 件)に必ずしも限定せず、ベンチ管理者が協議を行い、道路管 理者が指示する(神戸市)、あるいは交通結節点やコミュニティ道路 上に絞る(江戸川区)という自治体ごとの特色がある。上屋の占用者 は交通事業者のみ(5 件) と地縁組織等その他の団体にまで広げたも の(5 件)に分かれる。その構造は「幅 $2 \mathrm{~m}$ 以下」で統一されている。 主に広告掲載はその収入を管理費に補填する場合に認められており、 表示面に反射材料(5 件)を禁じる、またはイルミネーション、ネオン サイン、映像装置などを使用しないこと(名古屋市)を定めている。占 用場所は、主に一般の歩道においては「有効幅員 (0.5 3.5m 以上)」 (8 件)の箇所とされ、「幅員 $(2.5 \mathrm{~m}$ または $3 \mathrm{~m}$ 以上)」(2 件)を規定条 件とする都市は少ない。また、「バス停総合案内板」の規定は 2 件に
とどまる。「案内標識/公共表示板/掲示板」の寸法等具体規定は 9 件 みられ、地縁組織等主体のものには無余地性を定めたり (江戸川区)、 公共団体のみに認めるもの(千葉市)等、占用者の条件が異なった。以 上より、道路占用許可基準に関して明らかになった点を示す。 1)交通事業者や地域民間組織の関与可否は各空間要素や自治体方針 で判断が分かれる。また、上屋に関して沿道用途への言及はない。 つまり、2.1(2)の TBS 概念で重視される地元参加および周辺土地・ 建物利用との対応関係について必ずしも考慮されていない。 2)有効幅員の確保が重視される一方で、車道側か民地側かという位 置決めの規定は少ない。近年、地域のエリアマネジメントの一環で 結ばれる都市利便増進協定による沿道オープンカフェなどの占用物 件との連携に関する言及もない。

3)上記、連携がない場合、国の通達のベンチ寸法を参照すると、バ 
ス待ち行列以外の滞在可能人数は最大 4 人程度である。2)3)より、 沿道との接続性(「アクセスとつながり」に関連)、都市活動との近接 性や居場所の選択性(「快適性とイメージ」に関連) といった、2.1(2) の「場」の性能評価指標の観点が導入されていない。

したがって、国内バス停への「場」の機能の導入には、基準とは 別途、沿道との関係性(用途、歩道上の位置)、滞在空間づくりの総合 的方針を示寸計画が必要になるとみられる。

(2)基準を補完する各都市独自の施策

上記の総合的方針を、オープンスペースと一体的なバス停施策と して実験、策定する都市が現れている。本研究ではこうした施策が、 道路占用許可基準を補完し、場」の機能を導入しているとみて主調 查対象とする。近年の事例には 1)道路管理者主導: バス停周辺の路上 に寄付金によりベンチを増設する三鷹市(2006 年 )等、2)公共交通 事業者主導:バス停前面店舗や遊休地活用を行う京都市(2014 年 )等、 3)エリアマネジメント組織主導:バスベイ・バス停周辺公開空地・建 物および時間貸駐車場を対象に滞在環境向上実験を行った広島市 (2020 年)等、があるが市/区全域導入には未だ至っていない。本研究 の目的とする、空間デザインから維持管理に至る事業スキームに関 する知見を得るには、整備後の長年の管理-更新も含む実態把握が必 要である。そこで、東京都江戸川区主導のポケットパーク併設バス 停施策に着目する。国内ポケットパーク整備の初期事例 16) であり、 80 年代から先進的にバス停とオープンスペースの一体的運用を実 現したもので、区域内の約 9 割のバス停において環境高質化を実現 した後も、一部再整備も実施しているため、整備-管理-更新の事業ス キーム分析対象として選定する。

\section{3. 日本の路上結節点周辺環境の高質化スキーム}

本章では、主対象自治体を東京都江戸川区とし、国内の代表的施 策としてスキームの特徵を明らかにするため、江戸川区土木部保全 課及び水とみどりの課へのヒアリングおよび提供資料調查を行った。

\section{1 高質化スキーム}

(1)区の上位ビジョンとポケットパークの理念

江戸川区では、元来農業用水など水路網が豊かだったゆえに、急 激な都市化による水質污染が区民生活に与える影響が大きく、環境 行政に積極的に取り組んできた。60 年代から 1999 年まで継続した 中里区政主導の長期ビジョンによる基盤整備が進められた。区民生 活の向上と人間性の回復に寄与寸ることを目的に、1975 年に策定さ れた江戸川区長期総合計画(太陽とみどりの人間都市構想)に基づく 緑の文化都市が目指された。1974 年には全国初の親水公園を整備す るなど、自然回復や親水事業に関する調査研究、緑化思想の啓発普 及、公園事業の運営に力が入れられている。ポケットパーク併設バ ス停整備(1982 2002 年)もそうした流れの一環である。区内におい て鉄道網は東西をつなぐに留まり、南北移動を担うバスの重要度が 大きい。「アーバンリゾート都市」をキーワードに、バス待ちに合わ せて歩行者も休䄭できる空間をコンセプトに計 72 力所整備された。 (2)立地選定と空間要素

本事業は、まちづくりの意図をもった都市開発部と、公物整備・ 管理にあたる土木部の共同体制の下、実現した。当初は都市開発部 のみの発案であり、隅切りなど民地の残余地のみに計画される予定 だったが、土木部の参加を契機に、一定間隔で存在するバス停及び

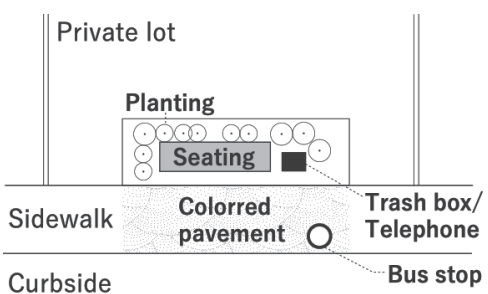

Fig.2 Spatial elements of a bus pocket park in Edogawa ward

\begin{tabular}{|l|l|}
\hline 1. Site Selection & 2. Contract with land owner \\
\hline Follow site priority terms & Proposal of furniture design \\
\hline $\begin{array}{l}\text { 3. Construction } \\
\text { by civil engineering dep. }\end{array}$ & C. Management \\
\hline $\begin{array}{l}\text { *Shelter: Use application or } \\
\text { granted by } \\
\text { bus operation companies }\end{array}$ & $\begin{array}{l}\text { **Planting: partially taken } \\
\text { care by volunteer groups }\end{array}$ \\
\hline
\end{tabular}

Fig.3 Scheme of pocket park increment

周辺歩道との一体的整備により、高齢者等の地域住民目線の空間が 実現できるとして、民地の活用を念頭においたポケットパークの構 成要素が整理された(Fig2,3)。民地用途については厳密な条件を設 けず、駐車場でもよいとされた。植え込みにより民地とは境界区分 され、歩道部カラー舖装など、道路部分との一体的デザインが図ら れた。円滑な整備のため、複数年次計画とし、条件が整った地区か ら順次選定した。ヒアリングによると「乗降客数の多いバス停」「「゙ ス事業者の要望」、将来のバスユーザー増加を見据えた「新規住宅開 発地付近」のいずれかを満たす場合に優先順位が高く設定された。 (3)整備

整備数を増やすために、以下の調整を行った。

1)道路占用許可基準上はバス事業者負担と定められる歩道上ベンチ を、附属物として道路管理者が設置した。整備・管理費とも区が負 担する。

2)比較的規模の大きい住宅開発地が発生した際に、民地の一部無償 使用契約(土地使用賃借契約: 1 年ごとに自動更新)の交渉を行った。 成立時には、固定資産税の減免を行う。当時は地権者・開発事業者 への広報パンフレットも作成された。現在も 400～500 戸規模の住 宅に対しては区との協議が定められている。

3)初期のポケットパークは、水路を暗渠とし、道路化・緑化する事 業に合わせて実現した。

(4)管理と更新

管理は土木部水とみどりの課が担う。公園管理の一環としてポケ ットパーク部分の植栽手入れ、シルバー人材センターに委託した週 3 回の清掃も行っている。コミュニティの特徴、あるいはカラー舗 装を区南北部で変更するなどの地域性を意識したデザインがなされ た。そのため、一部箇所では特注の素材を使用しており、破損の際 の取り換えや修繕が利かず、当時のオリジナルデザインの部分的継 承に留まる場合もある。民地上の管理方針については、無償契約の ため管理組合の意向が反映されやすい。住民の目が届く一方で、心゙ ンチでたむろするなどの利用行為に関しては、住民とバス停利用者 との摩擦がみられる。契約更新がなされず廃止したポケットパーク 併設バス停も出てきており、区の意向としては、地域貢献の事実を 可視化し、バス停利用者や関係者が自覚を持つように地権者側名称 の掲示板を出したいとしている。

(5)現在の新設および再整備 
想定箇所におけるバス停整備以後は、土木部による上屋、風防の 高質化事業が進んだ。代表事例として、古川親水公園停留所が挙げ られる。区が京成バスに依頼し、シャトルバス運行が開始された南 北方向路線沿いのバス停であり、路線の需要の高さから事業者が自 主的にバス停の高質化を行い、子会社による広告管理を実施してい る。区側は、今後、こうした広告収入を活かした事業者主導の再整 備が進むとみている。

\section{2 特徵と課題}

本事業は、開発系と土木系行政部署間の連携の下、バス停が備え るべき空間構成要素(Fig2 参照)、および優先的に整備する事業対象 地の条件を明確にしたこと(Fig3 参照)、また、民地側主体とバス事 業者の経済的負担を軽減するインセンティブ導入により実行できた と言える。小規模空間であるため、元来力を入れてきたオープンス ペース政策関連の公共事業に付随して、柔軟に財源を確保できたこ とも一因であろう。一方で、長期的管理の視点を踏まえると(1)更新 や再整備を行いにくい特殊な素材や設備を取り入れた点、(2)公共の 利用に開かれてはいるが、民地側主体の意向により環境管理の質が 左右される点、「場」の性能指標(2.1(2)Table5)の観点からは(3)まち づくりの意図があったにも関わらず、ポケットパークへの愛着を醸 成するなど、民地提供者あるいは周辺住民が自ら進んで管理を行う 動機付けまでには至らなかった点が、課題として挙げられる。

\section{4. バス停利用者の主観的意見に基づく「場」の性能評価}

こうしたスキームを踏んできた江戸川区内ポケットパーク併設バ ス停の「場」の性能を、バス停利用者の主観的意見から明らかにす る。第2章の指標 $(2.1(2)$ Table5)のうち、主観的意見および観察調查 から診断可能な「利用と活動状況」「快適性とイメージ」「利用者お よびコミュニティの交流・絆」指標を参照しながら、利用者属性・ 活動状況・活動の選択肢、満足度と管理状況への関心について聞き 取り調查( 2018 年冬季、平日 3 日間実施注3) を行った。バス待ち中の利 用者とその他の目的でポケットパークのベンチを利用する人々のい ずれも対象とした。実施地点はサンプル数が集まりやすい建物用途 前とし、なかでも一般バス停よりも着座可能人数が確保された公共 施設前(江戸川区役所,10系統, $\mathrm{n}=76$ ) と集合住宅前(なぎさニュータ ウン,8系統, $\mathrm{n}=36$ ) とした(Photo 2)。回答者の属性はFig4のとおりで、 性別にあまり偏りはない。高齢回答者が多いが、東京都市圈では高 齢者のほうが非高齢者よりもバスの占める交通分担率が高く17)、実 態に即したサンプルとなっている。また、区民が多数であり、4.1以 降の分析は地元利用者意見を反映したものとして位置付ける。

\section{1 利用パタン}

当該バス停へは 15 分圈内アクセスが $94 \%$ 占めた。ポケットパー ク部分の空間の日常利用者は回答者(有効回答 $\mathrm{n}=106)$ のおよそ 3 割 で、シーンに合わせて利用有無の判断をしている(次頁Fig5)。

ポケットパーク部分での滞在時間を尋ねると、バス待ち以外の目 的で 10 分以上の滞在者が多く、カイ 2 乗検定の結果、有意差が認 められた(次頁 Fig6)。合わせて実施した観察調査(350 名)では、バス 待ち以外の活動は計 24 件で、冬季ではあったが休䕀、会話、喫煙、 携帯電話・スマートフォン利用、待ち合わせ、写真撮影、軽食、花 壇の鑑賞、児童の遊び場としての利用パタンがみられた。

\section{2 設備への要望と管理への関心}

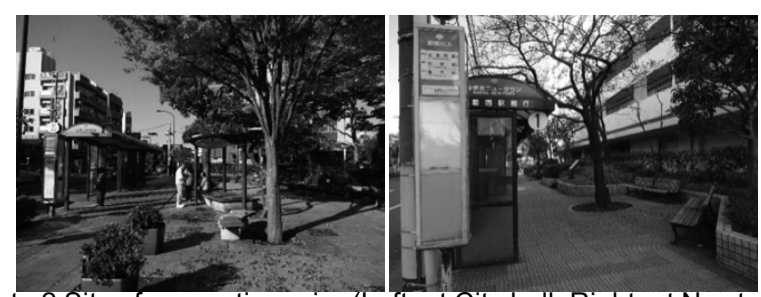

Photo 2 Sites for questionnaire (Left: at City hall, Right: at Newtown)

Living $\square$ in ward $\square$ outside of ward

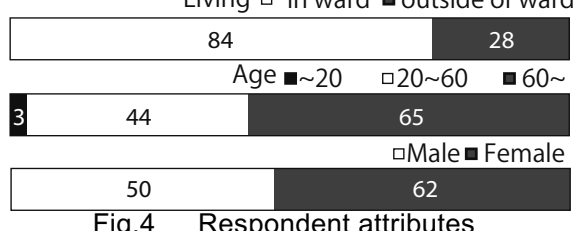

Fig.4 Respondent attributes

次記の (1) (3)より、現状設備に満足している層が7割程度で、3割 の改良を望む人々にはバスロケーション掲示版とゴミ箱の設置につ いて意見がみられた ((1)(2)参照)。そうした機能拡張には追加の管理 費がかかるが、それに対して負担意思を持つ層も3割程度おり、負担 意思の有無には、ポケットパーク、つまり公園としての認知と関連 性があるとみられる((3)参照)。

(1)現状設備への満足度

イスの数には $74 \%$ が現状に満足しており、 $15 \%$ が増設、 $11 \%$ が削 減を望んだ。面積については「十分に広い」と考える人は $31 \%$ 、逆 に「狭い」とする人は $8 \%$ にとどまり、「どちらとも言えない」とい う意見が大半を占めた。

(2)設置が望まれる設備

追加の設備設置の要望を述べたのは全体の約 $33 \%$ で、ニータウ ン前ではバスロケーション掲示板、不特定多数の人々がアクセスす る区役所前ではゴミ箱について、多くの回答を得た(次頁 Fig7)。

(3) コスト負担意思

江戸川区では、公園施設に対する寄附・基金が運用されており、 これをポケットパーク維持管理に充てられる可能性がある。そこで 「一般的な公園では、 $1 \mathrm{~m}^{2}$ (イス $1 \sim 2$ 人分収容可能な面積)を増設す ると、3000 円/年の維持管理費が上乗せされる。」注 4) という目安情 報を与え、回答者自身にかかるポケットパークの維持管理費増加を どの程度許容し得るか尋ねた(有効回答 $\mathrm{n}=112$ )。その結果、 $36 \%$ の 回答者が、大半が 1000 円以下の少額ではあるが増加を許容した (Fig8)。利用頻度や目的、自宅との近接性(自宅から 5 分未満でアク セスしたと回答した人)との関連は見出されなかった。他方でカイ 2 乗検定の結果、公園としての認知有利用者層（Fig9 左）と認知無利 用者層（Fig9 右）の間において負担意思有無に $1 \%$ 水準で有意差が 認められ、公園としての認知と負担意思には関連性があるといえる。

\section{3 利用者の主観的意見に基づく「場」の性能}

以上より、利用者は到着時刻直前にアクセスしがち、または比較 的高頻度の到着により待ち時間が短いという大都市の公共交通結節 点の特性より、ポケットパーク利用者は3割以下にとどまる。そのた め、そもそも関心があまりなく問題が過少評価された可能性もある が、問題点を挙げた回答者は少数かつ、バス待ち以外の利用もある ことから、「利用と活動状況」「快適性とイメージ」、「利用者および コミュニティの交流・絆」指標に関して、重大な課題はみられなか 


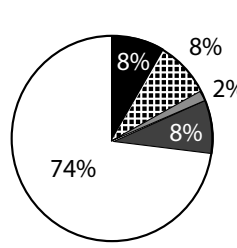

Fig. 5

Use cases of pocket park

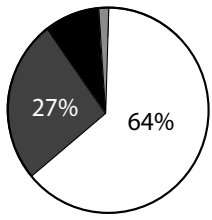

$\square 0 \mathrm{JPY} /$ year

$\square$ 1 300 JPY/year

ם 301 1000 JPY/year

$\square$ Over $1001 \mathrm{JPY} /$ year

Fig.8 Allowable maintenance cost by respondees
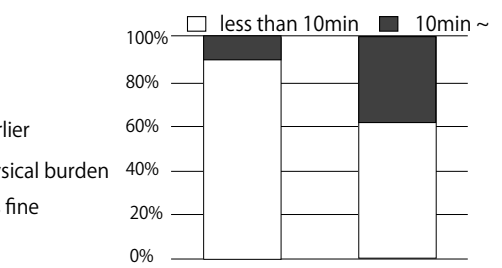

Fig.6 Bus waiting time and stay duration

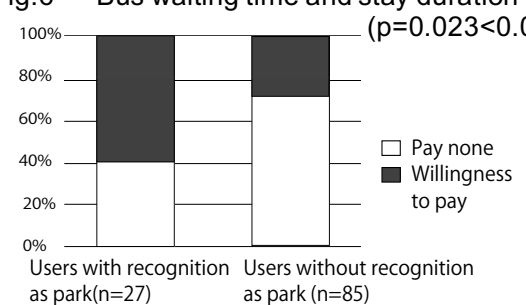

Fig.9 Recognition of pocket park and Willingness To pay $(P=0.003<0.01)$

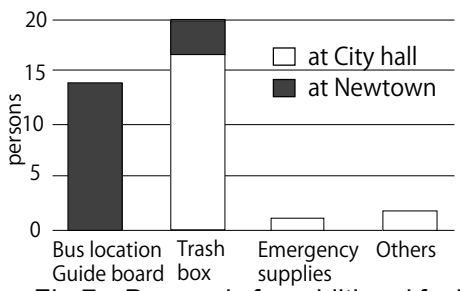

Fig.7 Demands for additional facility

Table 7 Contents of field survey

\begin{tabular}{|l|l|l|}
\hline $\begin{array}{l}\text { Site } \\
\text { (Number of } \\
\text { total } \\
\text { bus stops) }\end{array}$ & $\begin{array}{l}\text { Edogawa ward (62) } \\
\text { - Planned by the local } \\
\text { government }\end{array}$ & $\begin{array}{l}\text { Setagaya ward (4) } \\
\text { - Planned by Tokyu Bus } \\
\text { Cooperation }\end{array}$ \\
\hline Data & $\begin{array}{l}\text { - Customized furniture } \\
\text { - 1 stop is within the area } \\
\text { of district planning }\end{array}$ \\
\hline
\end{tabular}

つた。また、バス停利用者がポケットパークとして整備された空間 として認知することが管理等への関心向上につながると示唆された。

\section{5.「場」としての利用をもたらす空間要素}

さらに、江戸川区内全域のポケットパーク併設バス停に対象を広 げて、バス停間の空間要素の違いがバス利用者と地域住民(非バス利 用者)の「場」としての利用選択にもたらす影響を明らかにする。調 查概要はTable7のとおりである。

まず、主対象である江戸川区調査では空間要素としてバス停の位 置、面積、前面歩道の幅員、ベンチ利用可能人数、ベンチの位置、 前面施設の用途、セカンダリーシーティングの有無、バス停上屋の 有無、植栽の有無、バス停設備の破損状況を確認し、空間要素の位 置関係に関わる第 2 章「アクセスとつながり」指標の観点から評価を 行う。

また、 2 日間 $(9 \sim 17$ 時, 2017 年冬季調查注5) $)$ にわたり、バス待ち時 間1サイクル注6)の観察データを記録し、ポケットパーク利用(座位,立 位)がみられたか確認した。これらのデータを用いた多変量解析の結 果と、整備年代、住宅地域、運行間隔が15分以下のサービス水準の 高いバス路線沿いである点で江戸川区事例と共通するが、滞在空間 の設えが異なる既存 4 件の世田谷区ポケットパーク併設バス停全事 例の観察調查結果を合わせて、考察を行った。

\section{1 江戸川区ポケットパーク併設バス停空間現況と利用実態}

江戸川区では72件が整備されたが、廃止されたものもあるため(第 3 章)、現地踏查で存在が確認された 62 件を対象とする。

(1)分布

南北方向に通る東京都道307号の柴又街道(7件)、東京都道308号 の船堀街道己千葉街道(9件)、東京都道318号環状七号線(10件)、江戸 川に沿う篠崎街道(6件)に多くみられる。篠崎街道を除いては複数系 統が運行する区間である。鉄道駅徒歩圈( $300 \mathrm{~m}$ 圈)には 5 力所のみで、 必ずしも均一間隔での整備はなされていない(次頁Fig 10)。

\section{(2)空間構成及び前面用途}

さらにレイアウトの類型および代表平面をまとめた(次頁 Fig 11、 ベンチなし 2 件を集計值から除く)。道路構造令上、歩道幅員は最低 $2 \mathrm{~m}$ 、通行量が多い場合は $3.5 \mathrm{~m}$ 確保を位置づけている点を踏まえ、 歩道幅員に着目寸る。民地上のみベンチ設置事例(37 件, Type2)の
前面歩道幅員平均は $2.8 \mathrm{~m}$ (うち $2 \mathrm{~m}$ 以下 7 件)、歩道上ベンチ(Typ e1,3)がみられる場合は $3.7 \mathrm{~m}$ となっていた。したがって歩道幅の小 さい条件下においても、民地協力により、滞在と通行の両立が果た されている。Type 2 平面図に示すように、バス停とポケットパーク の使い分けや立位による滞在があり、利用ケースに応じた場所の選 択がなされていると言える。

次に規模と質に着目すると、50 件で植栽配置、中央値 4 名分 $\left(\mathrm{SD}=5.7\right.$, 中央值面積 $\left.21 \mathrm{~m}^{2}\right)$ の滞在可能な設備整備がなされ、規模の ばらつきは大きい。うち 19 件が $10 \mathrm{~m}^{2}$ 未満で、車いす利用者を踏ま えて一人あたり必要面積を $1 \mathrm{~m}^{2}$ とすると、滞在設備以外の余地が小 さい状況であった。滞在者が観測されたのは 33 件と全バス停の約 半数（次頁 Fig 12）、バス停あたり滞在者数の中央值は 1 名だった。 前面用途は、集合住宅あるいは戸建住宅の敷地の一部(25.0\%)、小中 学校や図書館、集会所等の公共施設に面したもの $(23.6 \%)$ が、多数を 占める(Fig 10)。うち、ポケットパークとバス停間の距離 $(6.7 \mathrm{~m})$ 、面 積 $\left(132 \mathrm{~m}^{2}\right)$ が確保された図書館前では、電話や高齢者同士の井戸端会 議が行われていた。他方で、破損、駐輪スペース化、ゴミがみられ た全7件は $30 \mathrm{~m}^{2}$ 以下であった。

以上より、「アクセスとつながり」指標の観点は概数満たしている が、[○6:他の交通手段の多様性]が確保できていないと言える。ま た、住民交流や利用マナーに面積が影響しているとみられる。 (3)各空間要素と滞在利用選択の関係

以上の調查より、1)ポケットパークとバス停間にある程度の距離 が確保され、歩行者や自転車との交錯も少ないこと、2)公共施設や 学校といった人が集う施設が前面用途になっていることが、滞在利 用選択に影響すると仮説をたて次頁Table8に示すX1-X10を説明変 数として整理した。座位滞在上限人数に関わるX3:ベンチ座席数、 X8:セカンダリーシティング有無の他に、前述1)に対応するX1:ポケ ットパーク面積、X2:歩道幅員、X4:ベンチのレイアウト、2)に対応 寸る前面用途 $(\mathrm{X} 5$ : 不特定多数利用の有無、X6:用途の公共性有無、X7: 建築物有無)を選定するとともに、その他の滞在快適性に関わる要素 としてX9:シェルター、X10:植栽を加えた。江戸川区における現地踏 查データ $\left(\right.$ 有効 $\mathrm{n}=61: 1$ サンプルのみ $900 \mathrm{~m}^{2}$ 規模だが、その他は $300 \mathrm{~m}^{2}$ 未満であるため、外孔值として除く。)を用いて、二項ロジスティッ ク回帰分析を行う。まず、各箇所で観測された滞在人数(最大值 6 人) 
を目的変数として、ポケットパーク滞在人数との相関注7の小さい、 3 変数 $(\mathrm{X} 1, \mathrm{X} 8, \mathrm{X} 9)$ を除いたうえで、説明変数間の相関を求めたとこ ろ、X5 とX6に強い相関がみられた。そこで、目的変数との相関が小 さいX5を除いた。残る6変数を説明変数、バス停への滞在有無を目 的変数とした二項ロジスティック回帰分析(ステップワイズ法)の結 果、X4:ベンチ位置とX6:用途2の2変数が有意であった。標準偏回帰 係数より多少ベンチ位置の影響度が高いと言える(Table9)。以上よ り、提示した空間要素の中では「ベンチ設置に対する民地協力」と 「不特定多数に開かれた施設前での設置」が、滞在利用選択に影響 するとみられる。ただし、 $\mathrm{R}^{2}$ 值、Nagelkerke $\mathrm{R}^{2}$ 值ともに值が小さ いため、次項の調查において他の要因の影響も考察する。

\section{2 世田谷区事例からみる運行状況と滞在利用の関係}

建物一体型上屋、特注ベンチ、民地建物や敷地との接続確保など、 江戸川区事例よりも踏み込んだ「ベンチ設置に対する民地協力」が みられ、かつ「不特定多数に開かれた施設前での設置」がなされた ポケットパーク併設バス停(4 件)が現存する世田谷区において各所 30 分間の観察調查を行った。(1)技術研究所前(上屋付き 2 列ベンチ)、 (2)医療機関前(シェルター付き)、(3)保育園前(建物一体型上屋)、(4) 飲食店前(日よけ兼モニュメント併設) と、同一路線上だが、民地上で 道路占用許可基準による制約に捉われないことを活かしたデザイン である。場所別のバス停利用者行動は以下のとおりで、延べ利用密 度の高かった(1)と(3)の調查結果を図示する。(次頁 Fig 13, Photo3) (1) 22 名利用:100 m²程度の面積で、 2 名以上バス停利用者による会

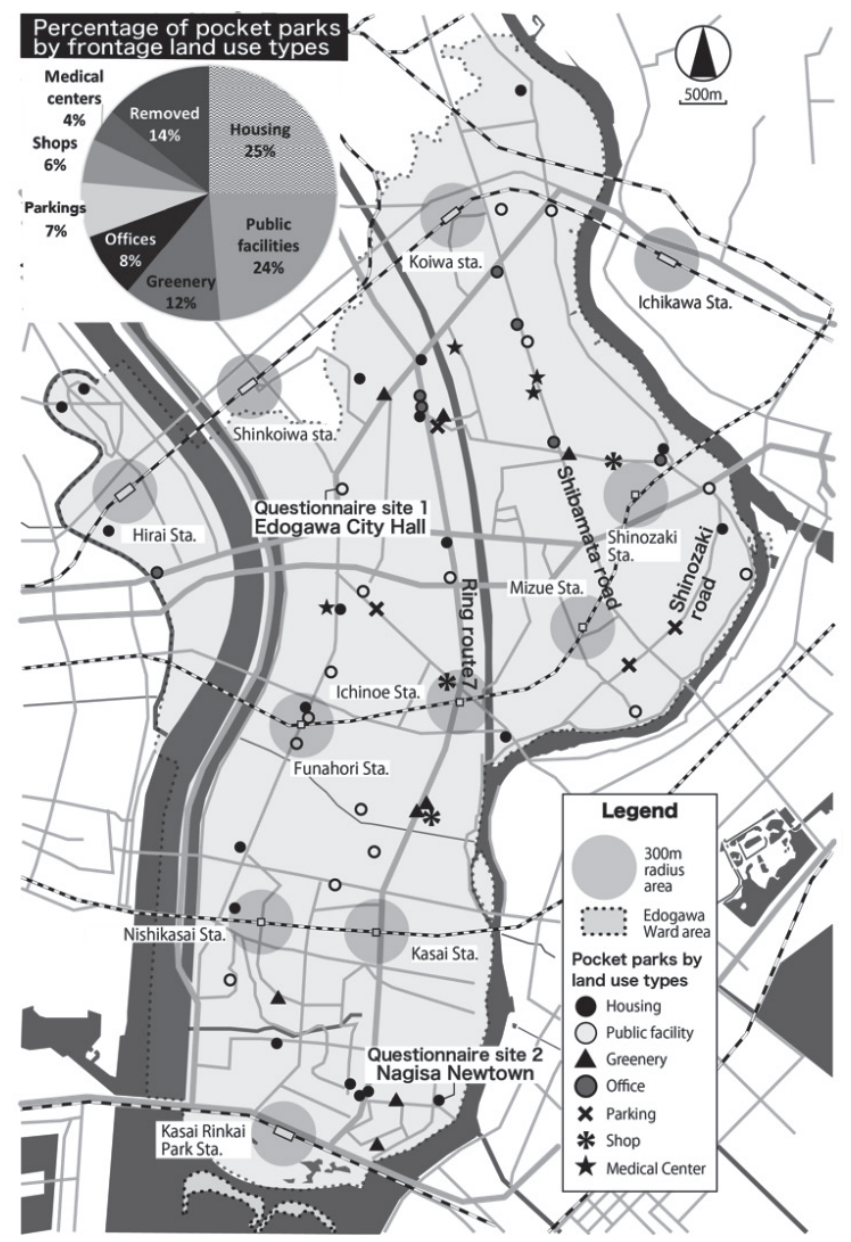

Fig.10 Location of Bus stops with pocket parks in Edogawa ward
話、待ち時間10分以上の利用が唯一見受けられた。一方でバス停の 上屋と風防が透明ではなく、ベンチに座ると横方向への視界が遮ら れる箇所があり、着席後、数回立って歩道に出てバスが来るかを確 認する行動(3名)が見受けられた。運転手側も同様にバス利用者が視 界に入りにくいとみられる。

(2)24 名利用:建物とポケットパークの接続部が設けられるとともに、 建物内に自由に出入りができ、休㮩スペースやカフェなどのバス待 ちできる箇所が多数存在するため、バス乗車 5 分前以内に建物から 出て、バス停に並ぶ行動が多くみられた。

(3)12 名利用:保育園関係者、隣接する医療機関通院者が中心に利用 寸るとみられ、バス停の利用が盛んであった。バスが視界に入るま

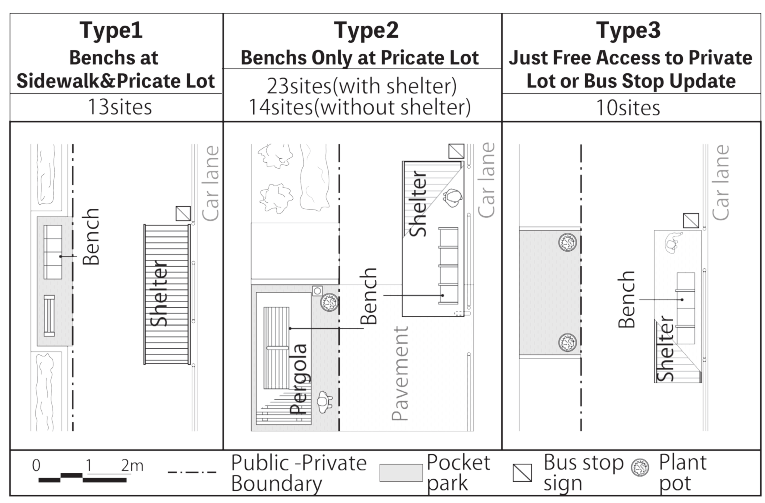

Fig.11 3 layout types of bus stop and pocket park

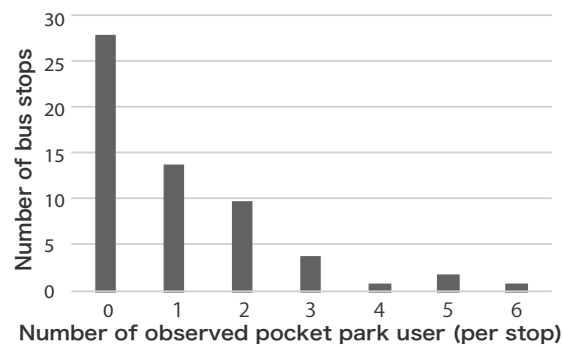

12. Number of

Table 8 Correlation between the number of stational users and each explanatory variable

\begin{tabular}{|c|c|c|c|c|c|c|c|}
\hline \multirow[b]{2}{*}{$\begin{array}{l}\text { Explanatory } \\
\text { variables }\end{array}$} & $\mathrm{X} 1$ & $\mathrm{X} 2$ & \multicolumn{2}{|c|}{$\mathrm{X3}$} & \multicolumn{2}{|l|}{$\mathrm{X} 4$} & X5 \\
\hline & $\begin{array}{l}\text { Pocket park } \\
\text { area size }\left(\mathrm{m}^{2}\right)\end{array}$ & $\begin{array}{l}\text { Width of } \\
\text { sidewalk } \\
\text { (m) }\end{array}$ & \multicolumn{2}{|c|}{$\begin{array}{l}\text { Possible user } \\
\text { no. of bench } \\
\text { (persons) }\end{array}$} & \multicolumn{2}{|c|}{\begin{tabular}{|l|} 
Layout of \\
bench \\
on sidewalk/ \\
in private lot /both
\end{tabular}} & $\begin{array}{l}\text { Land } \\
\text { use } 1 \\
\text { Openness } \\
\text { Yes/No }\end{array}$ \\
\hline \multirow[t]{2}{*}{$\begin{array}{l}\text { Correlation } \\
\text { coefficient }\end{array}$} & 0.005 & 0.170 & \multicolumn{2}{|c|}{$0.279^{*}$} & \multicolumn{2}{|c|}{$0.405^{* *}$} & 0.223 \\
\hline & $\mathrm{X} 6$ & \multicolumn{2}{|l|}{$\mathrm{X7}$} & \multicolumn{2}{|l|}{$\mathrm{X} 8$} & $\times 9$ & $\mathrm{X} 10$ \\
\hline $\begin{array}{l}\text { Explanatory } \\
\text { variables }\end{array}$ & $\begin{array}{l}\text { Land use2 } \\
\text { Publicness } \\
\text { Yes/No } \\
\end{array}$ & \multicolumn{2}{|c|}{$\begin{array}{l}\text { Land use3 } \\
\text { with Building } \\
\text { /no building } \\
\end{array}$} & \multicolumn{2}{|c|}{$\begin{array}{l}\text { Secondary } \\
\text { seating existence } \\
\text { Yes/No }\end{array}$} & $\begin{array}{l}\text { Shelter } \\
\text { Yes/No }\end{array}$ & $\begin{array}{l}\text { Planting } \\
\text { Yes/No }\end{array}$ \\
\hline $\begin{array}{l}\text { Correlation } \\
\text { coefficient }\end{array}$ & $0.323^{*}$ & \multicolumn{2}{|l|}{-0.150} & \multicolumn{2}{|c|}{0.079} & 0.094 & 0.175 \\
\hline
\end{tabular}

Table 9 Analysis of stational use choice (binary logistic regression analysis output)

\begin{tabular}{|c|c|c|c|c|c|c|}
\hline & & $\begin{array}{l}\text { Partial } \\
\text { regression } \\
\text { coefficient }\end{array}$ & $\begin{array}{l}\text { Standardized } \\
\text { partial } \\
\text { regression } \\
\text { coefficient }\end{array}$ & Odds ratio & p-value & $\begin{array}{l}\text { judge- } \\
\text { ment }\end{array}$ \\
\hline \multirow{3}{*}{$\begin{array}{l}\text { Explanatory } \\
\text { variables }\end{array}$} & X4Layout of bench & 1.531 & 0.988 & 4.625 & 0.010 & ** \\
\hline & X6Land use2 & 1.574 & 0.783 & 4.826 & 0.013 & * \\
\hline & X7Land use 3 & -1.448 & -0.627 & 0.235 & 0.073 & \\
\hline \multicolumn{2}{|c|}{ Constant term } & -0.892 & & 0.410 & 0.280 & \\
\hline \multirow{2}{*}{\multicolumn{2}{|c|}{ Coefficient of determination }} & $\mathbf{R}^{2}$ & Cox-Snell & Nagelkerke & \multirow{4}{*}{\multicolumn{2}{|c|}{$\begin{array}{r}*: \mathrm{P}<0.05 \\
* *: \mathrm{P}<0.01\end{array}$}} \\
\hline & & 0.236 & 0.278 & 0.372 & & \\
\hline \multicolumn{2}{|c|}{ Significance of regression equation } & \multicolumn{3}{|c|}{$p$-value $=0.0002$} & & \\
\hline \multicolumn{2}{|c|}{ Discriminative predictive value } & \multicolumn{3}{|c|}{$73.33 \%$} & & \\
\hline
\end{tabular}



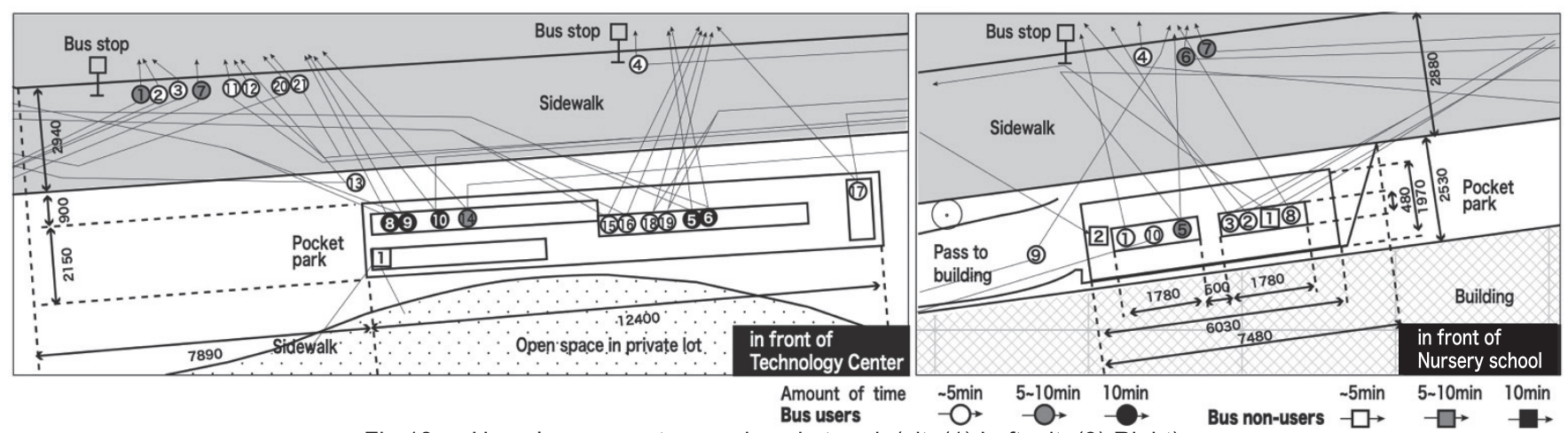

Fig.13 Users' movement around pocket park (site(1):Left, site(3):Right)
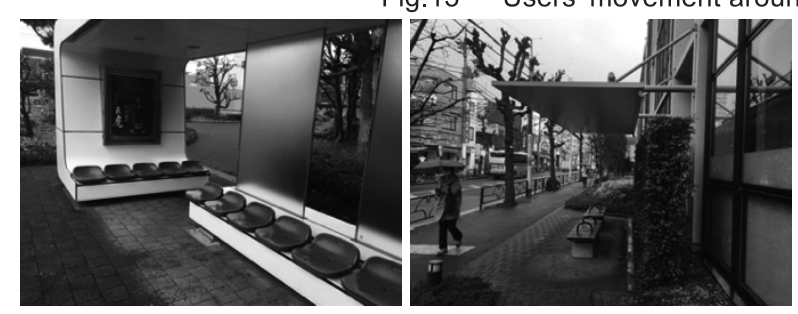

Photo 3 Photos of site(1)(Left) and site(3)(Right)

でベンチに滞在していた。

(4) 7 名利用:他 3 件と比べて歩道幅が狭く、歩行者動線とバス待ち行 列の交錯がみられた。バス待ちは大半が 5 分以内と短かった。

(1) (4)より、運行間隔が短いこともあり、屋外でのバス待ちは5分 程度であった。バス利用者のポケットパーク利用時間短縮要因とし ては、バス内座席確保の優先(バス待ち行列に加わる)、接近するバス への視界不良(気付いてもらうためにバス停に向かう)、バス停に直 接面した建物内での待ち空間の存在が挙げられる。

非バス利用者は全体で 4 名と少数であった。バス利用者にも関わ らず 10 分以上の滞在行動がみられた(1)について設備面では「歩道 からベンチ間のバッファー」のある奥行き確保、「道路に面したベン チと建物に面したベンチ双方の組み合わせ」、利用者の特性では「2 名以上利用者の存在、会話有り」という点で特徵的であった。

総括すると、バス利用者にとってはバス運行状況と滞在施設にお けるバス接近視覚情報の得やすさ、建物内待合空間の有無とアクセ スの 3 点、少数の非バス利用者にとっては、パーソナルスペースを 保てるベンチ位置とその奥行きが滞在行動に影響すると示唆された。

6. おわりに

本研究は、他と比較して長年かつ多数のオープンスペース一体型 バス停整備と運用の実績のある江戸川区施策を「場」の機能に配慮 した路上結節点事業スキームの代表事例として、また、江戸川区の 調查結果から示唆された「場」の性能発揮に必要な空間条件を備え ているとみられる世田谷区の結節点を空間デザインの代表事例とし て調查した。これらの調查結果により、2.2 に示した通行や安全管理 のしやすさに重点が置かれてきた現行の日本の道路関連制度による 制約、および4.3に示した大都市の公共交通結節点の特性のもとで、 実現可能な事業スキームと空間デザインの到達点と課題を示した。 下記に結論を示す。

\section{1 江戸川区におけるスキーム運用成果}

バス待ちと通行者による休䕀が共存できる空間づくりを目指した
江戸川区のポケットパーク併設型バス停事業は、行政部局間の連携 により、結節点の「場」の機能を考慮した国内初期事例であった。 計画〜管理段階を通じて、公共交通事業者、地権者との調整が肝要 とされたが、バス利用者や一般住民の参加プロセスは採られず、ポ ケットパークと沿道との接続や滞在施設のレイアウトは費用負担す る行政部局の方針で統一された。アンケート調查では、回答者の約 3割によるポケットパークの日常的利用が示された(第4章)。また、 区内ポケットパークの半数以上で滞在利用が確認され、ごく少数で はあるが冬期であっても多目的の利用パタンがみられた(第 4,5 章)。

以上より、江戸川区の目指した空間づくりは概ね達成されている と言えるが、管理段階において民地との契約廃止に至った事例が出 てきたことが課題であった(第3章)。そもそも公共交通利用に伴う空 間利用では、5 10分程度の滞在に限られ、空間への関心が集まりに くい中、定期的に利用し得る周辺住民や地権者による空間への愛着 醸成の仕組みが設けられていないことが原因である。

\section{2 国内大都市のバス結節点周辺環境の空間要素と配置のあり方}

滞在選択については「ベンチ設置に対する民地協力」「不特定多数 に開かれた施設前での設置」、利用時間の長さには「バス接近視覚情 報の得やすさ」「滞在空間の奥行きや余地」「建物との接続と建物内 待合空間」といった空間要素の影響が示唆された(第 5 章)。これらを、 第2章に示した「場」の性能指標を国内に応用寸る際に、追加または 重み付けす心゙き項目として提案する。

\section{3 国内大都市のバス結節点周辺環境事業スキームにおける留意点}

6.1に示した結節点空間管理への関心については、地域のオープン スペースとしての認知により㬇起される(第 4 章)。滞在利用のポテ ンシャルが高く、用地取得のハードルも比較的小さい公共施設前で、 オープンスペース施策としてのモデル空間運用を試し、認知を高め た上で、整備数を伸ばしていくことが望ましい。民間用地を確保す る場合、6.2より、「不特定多数に開かれた施設前」のバス停に面し た地点を優先的に選び、「バス接近視覚情報の得やすさ」と「滞在空 間の奥行きや余地」を満たす、公開空地や施設共用部等を活用す心゙ きである。

ただし、 $30 \mathrm{~m}^{2}$ 以下の用地では、人の滞在に魅力的とされず、凹地 によってできた死角がそれ以外の目的で用いられ、管理上の問題が 発生する恐れがある(第3 章)。「場」の機能の発揮に十分な用地の確 保には、残余地活用という消極的観点ではなく、用地提供者が積極 的に事業や不動産、エリアの価值向上につなげる動機付けが必要で あろう。そうした動機をもつのは地権者や沿道事業者が公共空間の 
管理に携わる意欲を持つエリアマネジメント型(2.2(2)の3)カテゴリ 一)の取り組みである。現在は、結節点と組み合わせた運用があまり 進んでいないが(第2 章)、それら主体が担う都市利便増進協定による 空間運用との連携も視野に入れるべきである。これにより、時間帯 ごとの歩道の通行需要と滞在需要に従い、配置や数量を変更できる 仮設物件占用による空間創出が可能である。プロセスの実装には、 通行需要への対応を主眼とした既存の道路占用許可基準とは別に、 結節点に隣接する官民空間を一体的に対象とし、面積水準の基準化 を行う必要がある。他方で、国内のスキームでは十分に触れられて いない地域活動や自転車等の他の交通手段との連携や調整を探る、 米国TBSの計画プロセス(第2 章)は、住民や地元利用者が結節点とそ の「場」の機能の社会的価值を予め共有し、整備や管理への参加の 動機付け機会となり得るとみられる。道路管理者や公共交通事業者 型(2.2(2)の1)、2)カテゴリー)においてTBSと同様のプロセスを踏む ことで、用地制約や管理の問題が緩和する可能性がある。

\section{4 今後の課題}

本研究は、バス停のハード整備にすでに力が入れられてきた国内 大都市の公共交通高頻度運行区間を対象に、調查を実施した。住民 等の参加プロセスの具体化や中小都市での有効性は、プレイスメイ キング実験を行うなど今後、検証を行っていく必要がある。

\section{謝辞}

本研究は国土交通省新道路技術会議・道路政策の質の向上に資す る技術開発研究「アジア都市における『場』の機能を持った道路計 画・運用に関する研究開発 (代表: 中村文彦, H28-30年度)」の一部と して行ったものである。ここにその謝意を表明いたします。

注

注1)例えば、横浜市南万騎が原駅駅、姫路市姫路駅前広場など

注2)国土交通省道路局長：「ベンチ及び上屋の道路占用の取扱いについて」の 一部改正について(国道利第 14 号平成 25 年 3 月 6 日) として通達

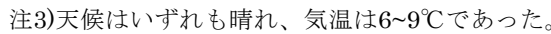

注4)増設分コスト単価については、(A) 東京都23区平均の単位面積あたり公 園維持管理費:約 800 円 $/ \mathrm{m}^{2} 、(\mathrm{~B})$ 新設木製ベンチ予算約 112000 円(最大 3 名掛 け可能 $\mathrm{w}=1900 \mathrm{~mm}) 、(\mathrm{C})$ ベンチの耐用年数を 15 年と設定し、(A) $+[1$ 座面 あたり換算した (B) $] /$ (C)式により概算し、3300円/ $/ \mathrm{m}^{2} か ゙$ 得られた。バス待ち 中の短期間で回答してもらうことを鑑み、百の位以下を切り捨てて、3000 円 $/ \mathrm{m}^{2}$ を用いることとした。(A)は、一般社団法人 日本公園緑地協会による 『平成27年度全国中核市等における公園緑地の課題に関する調查研究』、 (B)は環境省による『平成 27 年度自然公園等整備工事予算単価』の木製ベン チ単価に基づく。

注5)江戸川区調查時の天候は曇りまたは晴れ、気温 $9 \sim 15^{\circ} \mathrm{C} 、 世$ 、田谷区調查時

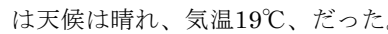

注6) 長期観察調查がより望ましいが、既往研究においてアクティビティ調查 では10 15分で路上の活動傾向を測るには十分とされており、江戸川区対 象バス停の件数が多数であるため、1サイクルとした。

注7)Fig12より、正規分布に従っていると仮定できないため、データの順位に 注目することとし、スピアマンの順位相関係数を求めた。

\section{参考文献}

1) N. Mitomo: Principles and Place Audit of Placemaking Through the Placemaking Concepts by PPS, THE 62st ANNUAL CONFERENCE OF JSSD, 62, 0, 33, 2015(in Japanese)

三友奈々:プレイスメイキングの定義・原則と場の評価項目に関する考察: プロジェクト・フォー・パブリックスペースによる原則と指針を通して, 日 本デザイン学会研究発表大会概要集, $62,0,33,2015$

2) F. Nakamura: Location of bus stops-Change of Location of Regional Facilities, Journal of Architecture and Building Science, pp.42-45, 2001 (in Japanese)
中村文彦: バス停の立地 地域施設の立地の変容, 建築雑誌, $16, p p .42-45$, 2001

3) T. Mizuta, Y. Kobayashi, Y. Himeno, S. Sato: Grasp of the Maintenance Situation of the Bus Stop and Study on Maintenance Standard in Oita City, AIJ Kyushu Chapter Architectural Research Meeting, 53, pp.265268, 2014 (in Japanese)

水田拓希，小林祐司，姫野由香，佐藤誠治:大分市におけるバス停留所の整 備状況の把握と整備基準に関寸る研究，日本建築学会九州支部研究報告， 53, pp.265-268, 2014

4) T. Hirahara, S. Hosokawa, Q. Zhao: A Study on the Influence of Waiting and Movement Behaviour on the Sidewalk Space around a Bus Stop (No.1), AIJ Kyushu Chapter Architectural Research Meeting, 43, pp.401-404, 2004 (in Japanese)

平原拓哉, 細川晋一郎, 趙世農: バス停周辺の歩道空間における待ち行動 と通過行動に関する研究(その 1 ), 日本建築学会九州支部研究報告, $43, \mathrm{pp}$. 401-404, 2004

5) Y. Takemoto: A study on Improving the Environment of Bus Stops by the Public and Private Sectors, JICE REPORT, 14, pp.54-59, 2008(in Japanese)

竹本由美:官民によるバス停環境整備に向けた調査研究, JICE REPORT vol.14, pp.54-59, 2008

6) T. Hirano, N. Omori, N. Harada, K. Ota: A Study on the Effects of Bus Waiting Behavior and Bus Stop Environment on Waiting Resistance, 22, Proceedings of the Conference of JSTE, pp.257-260, 2002 (in Japanese)

平野孝之, 大森宣暁, 原田昇, 太田勝敏:バス待ち行動とバス停環境が待 ち抵抗に与える影響に関する研究, 22 , 交通工学研究発表会論文報告集, pp.257-260, 2002

7) S. Hosokawa, T. Hirahara, Q. Zhao: A Study on the Influence of Waiting and Movement Behaviour on the Sidewalk Space around a Bus Stop (No.2), AIJ Kyushu Chapter Architectural Research Meeting, 43, pp. 405-408, 2004 (in Japanese)

細川晋一郎, 平原拓哉, 趙世農: バス停周辺の歩道空間における待ち行動 と通過行動に関する研究(その 2 ), 日本建築学会九州支部研究報告, $43, \mathrm{pp}$ 405-408, 2004

8) H.Suzuki, T. Honda: Study on lighting environment of bus stop with focuses on psychological effects, Journal of JSTE, 4, 3, p. A_40-46, 2018(in Japanese)

鈴木春菜, 本田達郎:屋外実験に基づいた心理的影響を考慮した快適なバ 又停照明についての研究, 交通工学論文集, 4, 3, p. A_40-46, 2018

9) TRANS-JAKARTA BUS RAPID TRANSIT SYSTEM TECHNICAL REVIEW, ITDP, 2003

10) MAYOR OF LONDON, Transport for London: Pedestrian Comfort Guidance for London, 2010

11) Transportation Research Board: The Role of Transit in Creating Livable Metropolitan Communities, TCRP Report 22, 1997

12) PROJECT FOR PUBLIC SPACES: Nicollet Mall: An Interim Report and Evaluation, 1987

13) C. Nikitin: Place-Defining Ridership-Building TOD: Thinking Beyond the Station To Create Community-Friendly Transit, BEST PRACTICES: COORDINATION OF TRANSIT, REGIONAL TRANSPORTATION PLANNING AND LAND USE CONFERENCE Presentation, 2007

14) PROJECT FOR PUBLIC SPACES: Transit-Friendly Streets: Design and Traffic Management Strategies to Support Livable Communities, TCRP Report, 33, Transportation Research Board, 1998

15) A. L. Sideris, J. Rojas: Developing Public Participation Tools in Transit Dependent Communities, Project for Public Spaces, 2014

16) M. Kumano, T. Kameno, T. Maruyama, M. Kamiura: The Purpose and Spatial Characteristics of Vest-pocket Parks in Japan, Journal of The Japanese Institute of Landscape Architecture, 65, 5, pp.801-804, 2001 (in Japanese)

熊野 稔, 亀野 辰三, 丸山 睴彦, 上浦 正樹:ポケットパークの設立目的と 空間特性, ランドスケープ研究, 65, 5, pp.801-804, 2001

17) Tokyo Metropolitan Area Transportation Planning Council: Issues and Direction of Response Regarding Urban Transportation in the Tokyo Metropolitan Area from the Viewpoint of Person Trip Survey, 2012(in Japanese)

東京都市圈交通計画協議会:パーソントリップ調查からみた東京都市圈の 都市交通に関する課題と対応の方向性, 2012 


\title{
A STUDY ON ‘PLACE’ FUNCTION OF THE BUILT ENVIRONMENT SURROUNDING
} BUS STOPS IN JAPANESE LARGE CITIES

\author{
Shino MIURA*1, Munehito YOSHIDA*2, Shinji TANAKA*3 \\ and Ryo ARIYOSHI*4 \\ ${ }^{* 1}$ Project Assist. Prof., Graduate School of Frontier Sciences, The Univ. of Tokyo, Dr.Env. \\ ${ }^{* 2}$ Engineer, Building Guidance Division of Kurashiki City Government, Dr.Env. \\ ${ }^{*} 3$ Assoc. Prof., Graduate School of Urban Innovation, Yokohama National Univ., Dr.Eng. \\ ${ }^{*} 4$ Project Assoc. Prof., Graduate School of Urban Innovation, Yokohama National Univ., Dr.Eng.
}

Enhancing the function of "place" is key to generate "user-oriented design". The research aims to clarify the spatial elements and their appropriate layout of the built environment surrounding bus stops co-existing with the function of "place" for street users, in consideration of dense Japanese urban contexts.

First, it conducted a literature review on international placemaking schemes. It found that a practical scheme named "Thinking beyond the Station" indicates there are 4 points of the index to measure the performance of "places". Subsequently, the research intended to find out how current bus stops in Japan perform as "place" for residents and bus users from the viewpoints of such place performance index and to designate the appropriate planning and management scheme.

Edogawa ward in Tokyo was selected as a case study site since it is a Japanese representative transit environment planning case coordinated with neighbor open spaces. The policy in the 1980s in the Edogawa ward prepared a comprehensive bus stop design scheme involving private landowners which are not seen in the general standards in other cities. The crosstabulation and multivariate analysis were implemented, applying the findings of the questionnaire and field survey to collect both subjective data of users' opinions to the bus stop environment and objective data of users' activity. As a result, bus users tend to access just before the arrival time of buses. The waiting time is short due to the relatively high frequency of arrival of the bus. The number of daily users in the pocket park portion is less than $30 \%$. Therefore, even there is a possibility that the issue of the pocket park was underestimated because there are many respondents with not much experience of use, the majority of the users pointed out no significant issues. Besides, it was suggested that the recognition of the pocket parks would lead to an increase in interest in management. The objective data revealed "private sector cooperation for bench installation" and "installation in front of the facility which is open to the general public" affect choices for staying. Because the R2 value is rather small, the observation survey at another sample in the Setagaya ward was also conducted to consider the additional possible factors to induce the user' $\mathrm{s}$ activities. The result suggested that "visual information of approaching bus", "depth and room of open space", "connection with a building or waiting space in building" may influence the length of use time.

The paper concluded that the frontage land use and location of the seating facility might influence users' stational activities by the results above. The mechanism to foster attachment to the place is also considered as keys to a better place. The spatial design scheme in Edogawa has shaped less attachment to the transit environment by local users and neighbors even though it has achieved most of the place performance index. The lack of attachment causes some cases of the abolition of agreement with landowners. The usage time associated with public transportation is too short time to gather interests in the environment. The mechanism should include a particular process to create recognition as a local open space. It also indicated the necessity of the lower limit setting of the size as an integrated open space to keep the quality of place. 